\title{
Margaret McCartney: Welfare is not a dirty word
}

\author{
Margaret McCartney, general practitioner
}

Glasgow

The UK chancellor's budget originally proposed to cut personal independence payments (PIPs) by $£ 1.3 \mathrm{bn}(€ 1.67 \mathrm{bn}$; $\$ 1.9 \mathrm{bn})$. An outcry, and a new secretary of state for welfare and pensions, reversed this proposal.

PIPs are not means tested and should allow people with disabilities to take part in life and work with equal opportunity. These payments should proudly promote equality. PIPs were overhauled from the old disability living allowance, supposedly to make savings. Because people may have been assessed only once, so the theory went, they may subsequently recover. This resulted in people with clearly lifelong, worsening, or terminal conditions being subjected to the stress of uncertain outcomes from medical examinations and then long delays in payments.

The organisations in a position to help with the complex forms, such as Citizens Advice, also had funds cut. ${ }^{1}$ The contracts were outsourced to companies that the National Audit Office has found to have missed performance targets. ${ }^{2}$

Over at employment and support allowance (formerly incapacity benefit)-for people who cannot work - cruel and inflexible sanctions have been applied to some, including a man who missed an appointment to attend to his partner having their stillborn child. ${ }^{3}$ These kinds of strains put pressure not just on patients and families but also on the NHS. A recent Channel 4 programme found some assessors boasting of making $£ 20000$ a month in incentives while denigrating patients. ${ }^{4}$

There are wider problems in how people on benefits are perceived. The researcher Adam Perkins has claimed a causal link whereby people "voluntarily increase contraceptive use if the generosity of benefits is reduced and vice versa." He wants benefits to be set at a level that reduces the number of children born to people claiming them, so that fewer children experience "personality damage due to being born into disadvantaged households." His use of statistics has been vigorously challenged. ${ }^{6}$

A paper that Perkins cited mentioned tax credits, for low paid people in work, as a supposed stimulus to reproduction. ${ }^{7}$ But is he seriously suggesting that already low paid people should be given less in benefits to encourage fewer children? These claims filtered into the media with little critical reflection.

British people are prouder of the NHS than of the royal family, the army, or Team GB. ${ }^{8}$ This reflects a proud British tradition of fair play: we take our place in long queues with a resigned patience, and we cheer on our national sports teams even when they have no chance of victory. Civic participation is dear and natural to us. Yet, when it comes to welfare, collective pride seems often to be replaced with simmering media outrage.

Good welfare is in our interest. When it fails, the NHS fills the gaps. We are not a country of "scroungers." Disability is normal, and our normal response should be one of pride in civil fairness.

\section{Competing interests: See www.bmj.com/about-bmj/freelance-} contributors/margaret-mccartney.

Provenance and peer review: Commissioned; not externally peer reviewed.

1 Citizens Advice. Cuts in CAB funding leaving thousands with nowhere to turn for help. 6 Sep 2011. https://www.citizensadvice.org.uk/about-us/how-citizens-advice-works/media/ press-releases/cuts-in-cab-funding-leaving-thousands-with-nowhere-to-turn-for-help/.

2 National Audit Office. Contracted out health and disability assessments. 8 Jan 2016. https: //www.nao.org.uk/wp-content/uploads/2016/01/Contracted-out-health-and-disabilityassessments-Summary.pdf.

3 Trussell Trust. Written evidence to parliament. 12 Dec 2014. http://bit.ly/1QCItFD.

4 Channel 4. Dispatches: the great benefits row. 11 Apr 2016. www.channel4.com/info/ press/news/the-great-benefits-row-channel-4-dispatches.

5 Perkins A. I was no platformed by student "radicals" for telling the truth about welfare. Telegraph $2016 \mathrm{Feb} 24$. www.telegraph.co.uk/education/universityeducation/12171532/ I-was-no-platformed-student-radicals-for-telling-the-truth-about-welfare.html.

6 Thomson J. Jonathan Portes replies to Adam Perkins. Psychological Comments (blog) 2016 Jan 14 http://drjamesthompson.blogspot.co.uk/2016/01/jonathan-portes-replies-toadam-perkins.html.

7 Brewer M, Ratcliffe A, Smith S. Institute for Fiscal Studies. Does welfare reform affect fertility? Evidence from the UK. 4 Nov 2008. www.ifs.org.uk/wps/wp0809.pdf.

8 Quigley A. Maintaining pride in the NHS: the challenge for the new NHS chief exec. Ipsos MORI. 8 May 2014. https://www.ipsos-mori.com/newsevents/blogs/makingsenseofsociety/ 1553/Maintaining-pride-in-the-NHS-The-challenge-for-the-new-NHS-Chief-Exec.aspx.

Published by the BMJ Publishing Group Limited. For permission to use (where not already granted under a licence) please go to http://group.bmj.com/group/rights-licensing/ permissions 